\title{
Evaluation of Different Groundnut Arachis hypogea L. Cultivars Against Termites, Odontotermes obesus (Rambur) in Rawalpindi, Pakistan
}

\author{
Muhammad Usman Malik ${ }^{1}$, Humayun Javed ${ }^{1}$, Mahmood Ayyaz $^{2^{*}}$ \\ ${ }^{1}$ Department of Entomology, Pir Mehr Ali Shah-Arid Agriculture University, 46300, Rawalpindi, Pakistan. \\ ${ }^{2}$ Department of Plant Production and Technologies, Faculty of Agricultural Sciences and Technologies, Niğde University, 51240 Niğde, Turkey.
}

\section{A R T I C LE INFO}

\section{Article history:}

Received 12 August 2014

Accepted 16 March 2015

Available online, ISSN: 2148-127X

Keywords:

Groundnut

Arachis hypogea $\mathrm{L}$

Odontotermes obesus

Screening

Termites

${ }^{*}$ Corresponding Author:

E-mail: masarwer@gmail.com

\begin{abstract}
A B S T R A C T
Six groundnut (Arachis hypogea L.) cultivars i.e. Golden, BARI-2000, Australian, BARD-479, ICG-7326 and 2KCGC20 were evaluated against the attack of Odontotermes obesus in terms of percentage infestation of workers and soldiers, their damage and impact on the yield. The maximum mean populations of $O$. obesus workers were recorded on 2KCGC20 (30.82 \pm 2.75 workers/plot) and Australian $(30.65 \pm 2.92$ workers/plot), followed by BARI 2000 (19.55 \pm 2.51 workers/plot), Golden (17.30 \pm 2.27 workers/plot) and BARD-479 (16.82 \pm 2.06 workers/plot). The minimum mean population of $O$. obesus workers was found on ICG-7326 cultivars $(14.85 \pm 1.81)$ workers/plot. The maximum mean population infestation of $O$. obesus soldiers was recorded on 2KCGC20 cultivar ( $4.88 \pm 0.25$ soldiers/plot) followed by Australian (4.15 \pm .30 , soldiers/per plot),

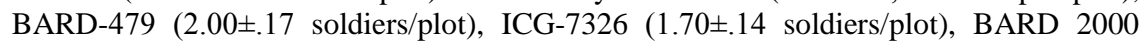
( $2.40 \pm .25$ soldiers/ plot). The minimum mean population of $O$. obesus soldiers was found

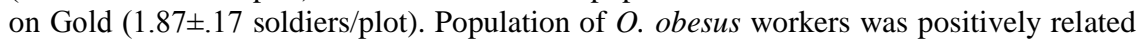
with the damage and negatively related the yield in all the groundnut cultivars.
\end{abstract}

\section{Introduction}

Groundnut (Arachis hypogea L.) belongs to family Fabaceae, is an important oil seed crop that contributes a major role in economy around the world (FAO, 2006; Narada et al., 2003; Nwokolo, 1996; Wiess, 2000). In Pakistan, this crop is considered as cash oilseed crop in the rain fed regions of Punjab (Hussain and Ahmed, 1984). It is the $3^{\text {rd }}$ most important source of vegetable protein and contains 50 percent edible oil, 28 percent digestible protein and 20 percent carbohydrates (Bhatti and Soomro, 1996; Christensen et al., 2004; Shah et al., 2012). It is a dietary source of vitamin E, phosphorus, $\mathrm{Mg}, \mathrm{Ca}, \mathrm{Zn}, \mathrm{Fe}$, thiamine riboflavin, and potassium and also used as diet of animals in the form of seeds, fodder, hay and straw (Smith, 2012). Groundnut is cultivated in tropical, subtropical and warm temperature climates (Carley and Fletcher, 1995). In Pakistan, more than 90 percent of the groundnut cultivated area is in the province of Punjab, of which approximately 87 percent area under cultivation is in Rawalpindi, Jhelum and Attock districts (Ahmed and Rahim, 2007; Hatam and Abbasi, 1994; Khan et al., 2009; Naeem-ud-din et al., 2009).

Despite of being an important oil seed crop, its per acre yield is still low in Pakistan due to unavailability of high yielding varieties, unprecedented environmental conditions, less rainfall and low inputs by the farmer (Khan et al., 1993). It is actually a stifling plant and requires an extended and hot growing period with optimum temperature $\left(25\right.$ to $\left.30^{\circ} \mathrm{C}\right)$ and optimum rainfall (500 mm) (Weiss, 2000). A well-drained sandy loam soils (pH 6.0-6.5) best thrive for groundnut (Basu and Ghosh, 1995).

Several factors are responsible for economic losses to groundnut crop such as variable rainfall, low soil fertility, crop management practices, pests and diseases (Naab et al., 2004). Several insect pests attack the groundnut crop that may cause moderate to severe damage (Javed et al., 2014). Among groundnut producing countries of Asia (including Pakistan) the major insect pest of groundnut include leaf miner, white grub, jassid, aphid, thrips, red hairy caterpillars and termites (Salihah et al., 1988; Sheirdil et al., 2012). Soil insect pests cause serious economic losses to groundnut crop (Wightman et al., 1990).

Termites $O$. obesus (Rambur) are social insects, attack on the tap root, feed out all contents ultimately replacing 
it with mud (Rawat et al., 1970). In case of sever attack, termite can cause 5 to 45 percent mortality of plants and 46 percent damages to pod (Kaushal and Deshpandy, 1967; Painter, 1951; Roonwal, 1981; Salihah et al., 1988). Different control methods such as cultural practices, biological control and application of plant extracts and insecticides are used to control termites (Ahmed and Nasir, 2008). The absolute reliance on chemical measures to manage the pests has created pesticides resistance and hazards to human and animal life and also increased the environment pollution around the world (Afzal, 2014; Bakhsh, 2009; Gold et al., 1996; Soerjani, 1998).

The use of termite resistant approved groundnut genotypes can be a very important dimension of integrated pest management (Painter, 1951). The major objective is to bridge the yield gap, ultimately making the groundnut as a profitable crop under rain fed conditions (Khan et al., 2009).

The Identification of termite resistant and high yielding varieties through screening can provide a convenient way for farmers to grow termite resistant groundnut cultivars for better yield. This ultimately will help to reduce the excessive use of insecticides on the crop leading to reduce the hazards to human and animal health and environmental pollution around the world (Soerjani, 1998). Host plant resistance (HPR) is a major constituent of integrated pest management (IPM) program that protects the crops by making it less susceptible for pest. Although, various successful attempts has been made for screening groundnut cultivars against termites with IPM techniques by Amin and Mohammad, (1982); Amin et al. (1985); Mohapatra et al. (1995) but resistance studies related to pod scarifying termites has yet not been reported so far in Pakistan. Therefore, keeping in view the potential threat of $O$. obesus to groundnut, the present study was conducted to evaluate some commercially grown groundnut cultivars against populations of $O$. obesus and resultant damage and yield losses.

\section{Material and Methods}

\section{Experimental Design and Plant Material}

The study was conducted at University Research Farm, PMAS-Arid Agriculture University, Rawalpindi, Pakistan. Six test groundnut varieties (Golden, BARI2000, Icg-7326, BARD-479, Australian, and 2KCGC20) were sown in a Randomized Complete Block Design (RCBD) with four replications during April, 2010. Seeds of (Golden, BARI-2000, ICG-7326) cultivars were obtained from Barani Agriculture Research Institute (BARI), Chakwal, Pakistan while seeds of (BARD-479, Australian, and 2KCGC20) cultivars were obtained from National Agriculture Research Centre (NARC), Islamabad, Pakistan. Seed rate was kept $80 \mathrm{~kg} \mathrm{ha}^{-1}$. The plot size was kept $4 \times 4.5 \mathrm{~m}^{2}$ for each replication with border size of $1 \mathrm{~m}$, respectively. Each plot comprised 10 rows of $3.6 \mathrm{~m}$ each and plant to plant and row to row distances were kept at 25 and $45 \mathrm{~cm}$, respectively. All agronomic practices (weeding, fertilizer application and irrigation) were strictly followed and no chemical measures were applied throughout the crop season to avoid any ill effect on population density of $O$. obesus.

\section{Detection for O. obesus population}

For the detection of $O$. obesus population (works and soldiers) in the experimental fields, four wood stacks (wrapped with blotting paper and tightened with rubber bands) of poplar (Populus fastigiata) tree were inserted vertically $25 \mathrm{~cm}$ deep into soil in each experimental plot and observed after a week interval to confirm the presence of termites in each tested plot. After confirming the presence of termites in all the tested plots, wooden stakes were replaced with NIFA-TERMAPS $®$ traps.

\section{Sampling for O. obesus population}

Sampling for termite's population was done by using NIFA-TERMAPS $®$ traps by developed trapping techniques (Salihah et al, 1988). For this purpose, traps were installed in each experimental plot. The trap comprised of a piece of plastic pipe $(15 \mathrm{~cm}$ diameter and $30 \mathrm{~cm}$ length) having inside the four pieces of ( $P$. fastigiata) wood of $16 \times 8 \mathrm{~cm}$ size (wrapped with blotting paper and tightened with rubber bands). For installation of traps, a hole of $30 \mathrm{~cm}$ depth and $20 \mathrm{~cm}$ diameter was made and position of trap pipe was kept approximately 5 $\mathrm{cm}$ above the soil surface. The observation was made 10 days after installation of traps. The observations were taken until 135 days after sowing (DAS) with 10 days interval.

\section{Level of susceptibility/receptivity}

Observation for number of workers and soldiers for each variety was recorded according to started 55 and 45 respectively, days after sowing (DAS) through visual observation and continued with 10 days of intervals. The level of susceptibility/receptivity of these varieties towards termites was estimated on the basis of infestation level per plot. Percentage infestation in plots of each cultivar was calculated according to the following formula:

$\%$ Infestation $=\frac{\text { Number of infested traps per plot per variety }}{\text { Total number of observed traps plot per variety }} \times 100$

\section{Statistical Analysis}

The experimental data was analyzed using computer software 'MSTATC' and means were compared by the Least Significant Difference at $0.05 \%$ of probability (Steel et al,. 1990).

\section{Results and Discussions}

\section{Trend of O. obesus workers population}

There was a significant difference in populations of $O$. obesus workers among all groundnut cultivars at all observation dates (Table 1). Golden cultivar was moderately resistant among all the tested cultivars having the minimum mean $O$. obesus workers population (17.30 \pm 2.27 individuals), while 2KCGC20 cultivar was highly susceptible with the maximum population 
(14.85 \pm 1.81 individuals) throughout the duration of the crop. The descending order of $O$. obesus workers' population in different groundnut cultivars was: Gold, BARD 2000, ICG-7326, BARD 479, Australian and 2KCGC20 respectively.

Observation for $O$. obesus workers population was started at (55 DAS). The population started to increase during (65-75 DAS). The highest population was recorded at $(105 \mathrm{DAS})$. The maximum population (67.00 workers/plot) was recorded on 2KCGC20 cultivar; statistically similar with Australian cultivar (66.00 workers/plot). The minimum population (49.75workers/plot) was recorded on Golden cultivar. The population infestation started to decrease gradually after (115 DAS). The minimum mean population infestation was recorded at 135 DAS on all tested groundnut cultivars (Table 1).

\section{Trend of $O$. obesus soldiers population}

There was a significant difference in populations of $O$. obesus soldiers among all groundnut cultivars at all observation dates (Table 2). It was observed that Golden cultivar was comparatively resistant among all six tested cultivars having the minimum infestation of soldiers (Average $=1.87 \pm 0.17$ ), while 2 KCGC cultivar was highly susceptible with the maximum $(4.88 \pm 0.25)$ mean soldiers infestation. The observations were taken until 135 days after sowing (DAS) with 10 days interval. The descending order of soldier population in groundnut cultivars was Gold, BARD 2000, ICG-7326, BARD 479, Australian and $2 \mathrm{KCGC} 20$ respectively.

Observation for soldiers' population was started 45 DAS. The population infestation of soldiers started to increase steadily during 65 to 75 DAS. The highest mean population of soldiers (7.50 soldiers/plot) was on Australian cultivar, statistically similar with 2KCGC cultivar (7.20 soldiers/plot) while the lowest mean population (4.50 soldiers/plot) was found on Golden cultivar at 105 DAS. The population infestation of soldiers started to decline 115 DAS. The minimum infestation of soldiers was recorded at 135 DAS on all tested groundnut cultivars (Table 2).

The correlation among populations of $O$. obesus workers and damage on different groundnut cultivar is shown in (Table 3$)$. There was significant $(\mathrm{P}<0.01)$ and positive correlation among populations of $O$. obesus workers and damage to all tested groundnut cultivars i.e. Golden (0.96), ICG-7326 (0.95), BARI-2000 (0.93), 2KCGC20 (0.89) BRAD-479 (0.88) Australian (0.74). These findings were in confirmation with Amin et al. (1985) that termite resistant groundnut verities expressed lower damage. Bhanot et al. (2009) reported positive correlation among $O$. obesus workers and damage in barley crop.

Table 1 Comparison of average $O$. obesus workers population at various intervals among groundnut cultivar

\begin{tabular}{l|lllllllll}
\hline Groundnut & \multicolumn{7}{|c}{ Mean O. obesus workers population (DAS) } \\
\cline { 2 - 10 } Cultivars & 55 & 65 & 75 & 85 & 95 & 105 & 115 & 125 & 135 \\
\hline 2Kcgc 20 & $3.75 \mathrm{a}$ & $23.00 \mathrm{a}$ & $22.75 \mathrm{a}$ & $33.25 \mathrm{a}$ & $43.75 \mathrm{a}$ & $67.00 \mathrm{a}$ & $44.25 \mathrm{a}$ & $18.75 \mathrm{a}$ & $31.0 \mathrm{a}$ \\
Australian & $3.25 \mathrm{a}$ & $20.50 \mathrm{a}$ & $22.00 \mathrm{a}$ & $36.25 \mathrm{a}$ & $46.50 \mathrm{a}$ & $66.00 \mathrm{a}$ & $45.75 \mathrm{a}$ & $17.25 \mathrm{a}$ & $33.75 \mathrm{a}$ \\
Bard-479 & $2.25 \mathrm{~b}$ & $8.00 \mathrm{~b}$ & $9.25 \mathrm{~b}$ & $19.00 \mathrm{~b}$ & $23.75 \mathrm{c}$ & $45.50 \mathrm{~cd}$ & $24.25 \mathrm{a}$ & $12.25 \mathrm{~b}$ & $16.75 \mathrm{bc}$ \\
Icg-7326 & $1.75 \mathrm{~b}$ & $8.25 \mathrm{~b}$ & $7.25 \mathrm{~b}$ & $14.75 \mathrm{c}$ & $22.25 \mathrm{c}$ & $10.75 \mathrm{~d}$ & $23.00 \mathrm{c}$ & $9.00 \mathrm{c}$ & $14.25 \mathrm{c}$ \\
Bari 2000 & $1.75 \mathrm{~b}$ & $6.75 \mathrm{~b}$ & $9.50 \mathrm{~b}$ & $21.50 \mathrm{~b}$ & $32.75 \mathrm{~b}$ & $53.75 \mathrm{~b}$ & $32.50 \mathrm{~b}$ & $11.75 \mathrm{bc}$ & $21.00 \mathrm{~b}$ \\
Golden & $1.00 \mathrm{c}$ & $6.00 \mathrm{~b}$ & $9.50 \mathrm{~b}$ & $18.75 \mathrm{~b}$ & $28.50 \mathrm{bc}$ & $49.75 \mathrm{bc}$ & $28.75 \mathrm{bc}$ & $1.25 \mathrm{bc}$ & $16.25 \mathrm{c}$ \\
LSD at 0.05 & 0.70 & 2.55 & 2.92 & 3.74 & 6.44 & 8.93 & 5.92 & 3.01 & 4.7 \\
Frequency & 19.33 & 80.05 & 52.47 & 49.29 & 22.35 & 13.58 & 25.05 & 14.38 & 27.99 \\
\hline
\end{tabular}

*Mean values followed by the different letter in the same column are statistically different $(\mathrm{P} \leq 0.05, \mathrm{D} . \mathrm{F}=15)$

Table 2 Comparison of average $O$. obesus soldiers population at various intervals among groundnut cultivar

\begin{tabular}{l|llllllllll}
\hline \multirow{2}{*}{ Cultivar } & \multicolumn{10}{c}{ Mean O. obesus soliders population (DAS) } \\
\cline { 2 - 10 } & 45 & 55 & 65 & 75 & 85 & 95 & 105 & 115 & 125 & 135 \\
\hline 2Kcgc 20 & $3.00 \mathrm{a}$ & $4.50 \mathrm{a}$ & $4.50 \mathrm{a}$ & $5.50 \mathrm{a}$ & $5.25 \mathrm{a}$ & $7.00 \mathrm{a}$ & $7.20 \mathrm{a}$ & $5.25 \mathrm{a}$ & $2.75 \mathrm{a}$ & $3.75 \mathrm{a}$ \\
Australian & $1.75 \mathrm{~b}$ & $2.00 \mathrm{~b}$ & $2.00 \mathrm{~b}$ & $4.75 \mathrm{a}$ & $4.75 \mathrm{a}$ & $6.75 \mathrm{a}$ & $7.50 \mathrm{a}$ & $4.50 \mathrm{a}$ & $2.50 \mathrm{a}$ & $2.75 \mathrm{~b}$ \\
Brad-479 & $1.00 \mathrm{c}$ & $1.00 \mathrm{c}$ & $1.00 \mathrm{c}$ & $1.25 \mathrm{c}$ & $2.50 \mathrm{~b}$ & $3.00 \mathrm{bc}$ & $4.50 \mathrm{bc}$ & $1.75 \mathrm{~b}$ & $1.00 \mathrm{~b}$ & $2.25 \mathrm{bc}$ \\
Icg-7326 & $1.00 \mathrm{c}$ & $1.00 \mathrm{c}$ & $1.00 \mathrm{c}$ & $1.25 \mathrm{c}$ & $2.00 \mathrm{~b}$ & $2.25 \mathrm{c}$ & $3.70 \mathrm{c}$ & $2.00 \mathrm{~b}$ & $1.00 \mathrm{~b}$ & $1.75 \mathrm{c}$ \\
Bari 2000 & $1.00 \mathrm{c}$ & $1.25 \mathrm{~b}$ & $1.25 \mathrm{~b}$ & $2.25 \mathrm{~b}$ & $2.75 \mathrm{~b}$ & $4.00 \mathrm{~b}$ & $5.70 \mathrm{a}$ & $2.25 \mathrm{~b}$ & $1.25 \mathrm{~b}$ & $2.00 \mathrm{c}$ \\
Golden & $1.00 \mathrm{c}$ & $1.00 \mathrm{c}$ & $1.00 \mathrm{c}$ & $1.25 \mathrm{c}$ & $2.00 \mathrm{~b}$ & $7.00 \mathrm{a}$ & $4.50 \mathrm{a}$ & $2.50 \mathrm{~b}$ & $1.00 \mathrm{~b}$ & $1.75 \mathrm{c}$ \\
LSD at 0.05 & 0.30 & 0.44 & 0.69 & 0.80 & 0.88 & 1.32 & 1.46 & 0.85 & 0.50 & 0.70 \\
F-value & 63.40 & 88.74 & 45.32 & 51.87 & 51.87 & 23.14 & 10.35 & 26.74 & 33.00 & 10.82 \\
\hline
\end{tabular}

*Mean values followed by the different letter in the same column are statistically different ( $\mathrm{P} \leq 0.05, \mathrm{D} . \mathrm{F}=15)$ 
Table 3 Correlation among populations of $O$. obesus workers, damage and yield on tested cultivars.

\begin{tabular}{l|ccc}
\hline Cultivars & $\begin{array}{c}\text { Correlation among populations of O. } \\
\text { obesus workers and damage on groundnut } \\
\text { cultivars }\end{array}$ & $\begin{array}{c}\text { Correlation among populations of O. } \\
\text { obesus workers and yield of groundnut } \\
\text { cultivars }\end{array}$ \\
\hline Golden & 0.96 & -0.83 \\
Bari-2000 & 0.93 & Significant & -0.96 \\
Australian & 0.74 & at P $\leq 0.001$ & -0.79 \\
Brad-479 & 0.88 & & -0.89 \\
Icg-7326 & 0.95 & -0.72 \\
2 kcgc 20 & 0.89 & -0.95 \\
\hline
\end{tabular}

The correlation among populations of $O$. obesus worker and impact on yield of targeted groundnut cultivar is shown in Table (3). There was a significant $(\mathrm{P}<0.01)$ and negative correlation among populations of $O$. obesus workers and their impact on the yield of all test ground cultivars i.e. BARI-2000 (-0.96), 2KCGC20 (-0.95), BRAD-479 (-0.89), Golden (-0.83), Australian (-0.79) and ICG-7326 (-0.72). These finding were confirmatory with Mohapatra et al. (1995) who screened 23 groundnut varieties, four varieties were resistant to termites while other tested varieties were less susceptible to termite attack but simultaneously gave high yield of groundnut pod under field conditions. Our studies results related to O. obesus worker and soldiers are in agreement with the results of (Ijaz and Aslam, 2003) who reported that difference in mean infestation of $O$. Obesus may be due to crop vigorous. Preference and non-preference of $O$. Obesus might be due to chemical nature of plant wood, level of moisture content, concentration of cellulose and lignin in plant primarily due to the fact that termites prefer to attack on plants having high concentrations of cellulose (Judd and Corbin, 2009; McMahan, 1966). Further, fluctuations of termite's population might be due to influence of abiotic factors. The above findings are in accordance with the Al-Hemyari (1994) who reported that rise and fall in temperature may influence on the foraging activity of termites. However rain fall can induce a suitable temperature and humidity for termites foraging activity as reported by Akhter and Amanullah (1989).

\section{Conclusion}

The Australian and 2KCGC-20 were found to be comparatively more susceptible cultivars due to maximum $O$. obesus infestation while ICG-7326 and Golden cultivars seemed to be less susceptible due to minimum infestation. Based on our results finding, ICG7326 and Golden cultivars can be recommended as comparatively resistant to termites attack for the farmers of Pothwar region of Pakistan.

\section{Acknowledgements}

The authors acknowledge National Agriculture Research Centre (NARC), Islamabad Pakistan and Barani Agriculture Research Institute (BARI), Chakwal, Pakistan for providing the seed of groundnut cultivars for experiment.

\section{References}

Ahmad N, Rahim M. 2007. Evaluation of promising groundnut Arachis hypogaea L. varieties for yield and other characters. J. Agric. Res., 45: 185-189.

Amin PW, McDonald D. 1981. Termites as pests of groundnut. In Veersh G.K. (Ed.). Progress in Soil Biology and Ecology in India, Bangalore. UAS Technical Series No. 37: 273-278.

Ahmed S, Nasir. M. 2008. Integrated approach of management of termites in sugarcane. Pak. Entomol., 30:127-132.

Al-Hemyari AA. 1994. Factors affecting foraging activity of Microtermes yemenensis (Isoptera: Termitidae). Ann. Agric. Sci., Moshtohor, 32: 987-995.

Akhter MS, Amanullah. 1989. Swarming behavior of termites at Punjab University, new campus Lahore. Pak. J. Zool., 21: 229237.

Amin PW, Mohammad AB.1982. ICRISAT's research in groundnut entomology. ICRISAT, Patancheru India., 82: 34.

Amin PW, Singh KN, Dwivedi SL, Rao VR. 1985. Sources of Resistance to the jassid (Empoasca kerri Pruthi), thrips (Frankliniella schultzei (Trybom) and termites (Odontotermes sp.) in Groundnut (Arachis hypogaea L.). Pean. Sci., 12: 5860.

Bakhsh A, Rao AQ, Shahid AA, Husnain T, Riazuddin S. 2009. Insect resistance and risk assessment studies in advance lines of Bt cotton harbouring crylAc and cry $2 A$ genes. Am. Eur. J. Agric. Environ. Sci., 6: 1-11

BASU MS, Ghosh PK. 1995. The status of technologies used to achieve high groundnut yields in India. In: Achieving high groundnut yields. ICRISAT, Patancheru, India.

Bhanot JP, Verma AN, Kashyap RK. 2009. Population dynamics of termites in barley fields and correlation between termite population and termite damage. Z. Angew. Entomol., 98: 234238.

Bhatti LM, Soomro AH. 1996. Agriculture inputs and field crop production in Sindh. Agri. Res. Sindh, 56-69.

Carley DH, Fletcher SM. 1995. An overview of world peanut market, In: (ed.) Pattee H.E. and H.T. Stalker, Advances in peanut science, Amazon Peanut Res. and Educ. Soc. Inc., Stillwater, Ok, 554-557.

Christensen JH, Olesen JE, Feddersen OH, Andersen UJ, Heckrath G, Harpoth R, Andersen LW. 2004. Application of seasonal climate forecasts for improved management of crops in western Africa. Danish Climate Centre, Report 03-02, pp. 17.

FAO. 2006. FAO production yearbook, Vol. 60, Rome, Italy.

Gold RE, Howell HN, Pawson BM, Wright MS, Lutz JC. 1996. Persistence and bioavailability of termiticides to subterranean termites (Isoptera) from five soil types and locations in Texas. Sociobiol., 28: 337-363.

Hatam M, Abbasi GQ. 1994. Oilseed crops. In: Crop production. (Ed.) S. Nazir, E. Bashirand R. Bantel. National Book Foundation, Islamabad. 329-389.

Hussain N, Ahmed CR. 1984. Problems of groundnut cultivation in the representative areas of Punjab Lahore, Pakistan: Punjab Department of Agriculture. pp. 1-14. 
Ijaz M, Aslam M. 2003. Infestation Trend of Odontotermes obesus (Rambur) on Wheat Crop (Triticum aestivum Linnaeus) in rainfed Conditions. Asian J. Plant Sci., 2: 699-701.

Javed H, Javaid I, Mateen, Z. 2014. Response of Different Cultivars of Groundnut, Aarachis hypogaea L. (Fabaceae: Fabales) to Aphids, Aphis craccivora K. (Aphididae: Homoptera) in Interaction With Local Weather Factors. Pak. J. Zool., 46: 7581.

Judd TM, Corbin CC. 2009. Effect of Cellulose Concentration on the feeding preferences of the Termite Reticulitermes flavipes (Isoptera: Rhinotermitidae). Sociobiol. 53: 775-784.

Kaushal PK, Deshpandy RR. 1967. Losses to groundnut by termites. J.N. Krishi Vishwavidyalaya Res. J. Jabalpur, 1: 92-93.

Khan AM, Rahim Malik NJ, Khan A. 1993. Phenotypic stability of pod yield and related characters in bunch type peanut genotypes. Sarhad J. Agric., 14: 441-446.

Khan AA, Hussain I, Munir S. 2009. Control of rodent damage to groundnuts in the Pothwar plateau region of Pakistan. Pak. J. Zool., 41: 203-207.

McMahan EA. 1966. Studies of Termite Wood-feeding Preferences. Department of Zoology, University of North Carolina,15: 239249.

Mohapatra HK, Padhi J, Samalo AP, Patra GJ. 1995. Screeningpromising ground- nut varieties against termite damage at Bhubaneswar, Orissa, India. IAN., 15: 59-60.

Naab JB, Singh P, Boote KJ, Jones JW, Marfo KO. 2004. Using the CROPGRO-Peanut Model to Quantify Yield Gaps of Peanut in the Guinean Savanna Zone of Ghana. Agron. J. Amer., 96: $1231-1242$.

Naeem-ud-Din, Mamood A, Khattak GSS, Saeed I, Hassan MF. 2009. High yielding groundnut (Arachis hypogea L.) variety golden. Pak. J. Bot., 41: 2217-2222

Narda NK, Thaman S, Lubana PPS. 2003. Growth and yield of summer planted bunch groundnut (Arachis hypogaea) as influenced by irrigation methods. Indian J. Agric. Res., 73:167168.
Nwokolo E. 1996. Peanut (Arachis hypogaea L.). In: Food and fee from legumes and oilseeds (eds. E. Nwokolo and J. Smartt). Chapman and Hall, New York, pp. 49-63.

Painter RH. 1951. Insect resistance in plant crops. McMillan, New York.

Rawat RR, Deshpande, Kaushal PK. 1970. Comparative efficacy of different modern insecticides and their method of application for control of termites, Odontotermes obesus in groundnut, Arachis hypogea, Madras. Agric. J., 57: 83-87.

Roonwal ML. 1981. Termites of agriculture importance in india and their control. In progress in soil biology and ecology in India" (Vereesh, G.K.ed). Tech Ser. 37. Univagric Sci. Bangalore. 253-256.

Salihah Z, Shah M, Sattar A. 1988. Survey of sugarcane termites of Nowshera and Charsada tehsils. Proceeding of $8^{\text {th }}$ Pakistan congress of Zoology, 8: 289-297.

Shah H, Khan MA, Azeem T, Majid A, Mehmood A. 2012. The impact of gypsum application on groundnut yield in rainfed Pothwar: an economic perspective. Lahore J. Econ., 17: 83-100

Sheirdil RA, Mahmood A, Khan RU, Khalid R, Amara U. 2012. Groundnut; a crop for subsistence in edible oil production in Pakistan. In: Agrihunt. Retrieved October, 30, 2013. From http://www.agrihunt.com/major-crops/45-groundnut-acrop-forsubsistence-in-edible-oil-production-inpakistan.html

SMITH AF. 2002. Peanuts: The illustrious history of the goober pea. University of Illinois Press, Chicago.

Soerjani M. 1998. Current trend in pesticide use in some Asia countries. Envir. Implic. Res. Pesticide, Res. Pesticide., Int. Atomic Energy Agency, Viena, Austria, 314-319.

Steel RGD, Torrie JH, Dickey DA. 1990. Principles and procedure of Statistics: A Biometrical Approach, $3^{\text {rd }}$ edition, WCB Mc Graw Hill Companies, Inc., USA.

Weiss EA. 2000. Oilseed Crops. London: Blackwell Science.

Wightman JA, Dick KM, Ranga-Rao GV, Shanower TG, Gold CG. 1990. Pests of groundnut in the semi-arid tropics. In: Insect pests of tropical food legumes. John Wiley and Sons, Chichester, England, UK, 243-322. 